\title{
SCAPEGOATS AND TRAGIC HEROES: USING ARCHETYPAL PATTERNS IN SHORT STORIES
}

\author{
Alberta Natasia Adji | Edith Cowan University
}

\begin{abstract}
Literary motifs such as archetypes can be very defining in short stories, since they provide the patterns that both authors and readers can easily resonate with. Studies have shown that archetypes are useful elements in the process of narrative patterning in literature. This paper explores the use of the Scapegoat and the Tragic Hero archetypes in my two short stories, 'Her Tale on Earth' (2014) and 'The Day She Walked Out of the Gates' (2014), to show how experimenting with these archetypes helped determine the shape of the each story's structure, genre, and eventually the final form of each piece. While I was not immediately aware of my preferred character patterns, communicating my purpose through the stories led me to discover the right archetypes for my intentions. These stories are about characters who face adversity because of their complex parentage or heritage: themes which fuel my PhD research.
\end{abstract}

BIOGRAPHICAL NOTE

Alberta Natasia Adji is a creative writing $\mathrm{PhD}$ candidate at Edith Cowan University. Her novel and exegesis are concerned with complex ethnic relations in Indonesia, autobiographical fiction, and life writing. She has published two novels, Youth Adagio (2013) and Dante: The Faery and the Wizard (2014), and some short stories in Jawa Pos, an Indonesian national daily newspaper based in Surabaya. 
Archetypes are applied to identify certain statements, patterns of behaviour, or prototypes based on the primitive or archaic underlying image which exists in the collective unconscious. Archetypes integrate the universal with the individual and the commonplace with the peculiar, making them familiar to all humankind; at the same time, they exist within every human entity, in some ways making the individuals themselves feel astonished at how they might possess such propositions within themselves (Stevens 1994: 49-50). In literature, archetypes have long been recognised as the universal literary motifs which come with distinguishable characters, themes, and situations that can be easily found in myths, religious teachings, and folklores (Evans 1971: 3).

In relation to how archetypes might inspire the production of narrative work, Carl Jung and Joan Chodorow state that brilliant ideas and all forms of creative work are the brainchildren of our imagination and fantasy (1997: 5). Indeed, the birth of any creative work should be credited to the play of imagination, the active fantasy, which, in its basic sense, is contradictory to the concept of serious work (Jung 1997: 5). Jung and Chodorow highlight the significance of active fantasy, which is an active attitude toward one's fantasies, allowing us to embrace the unconscious with such an enthusiastic approach that it eventually gives new energy and recognition to the unsorted materials appearing from the unconscious (1997: 6). In this way, I argue that archetypes, which have prevailed within the unconscious of humanity, can serve as the materials necessary to fuel creative work-including narrative writing-when they are met with an active attitude toward one's fantasies, as I myself discovered.

The initial forms of two of my own short stories emerged from a desire to express my own experiences of complex ethnic relations within a community setting. The first story, 'Her Tale on Earth', written in 2014, draws from my own experience as a double ethnic minority (Chinese Christian) who joined a student community of nearly allethnic majority (Javanese Muslim) members in Indonesia. The second story, 'The Day She Walked Out of the Gates', was inspired by a friend's experience of living a complex life as a child of mixed-ethnic and intercultural parentage. I found the Scapegoat archetypal character in the first story and the Tragic Hero in the second to be helpful elements in determining the role of the characters and shaping the whole narrative.

In weaving stories drawn from personal experience, I used narrative inquiry as my methodology since it is 'the study of experience as story' and is 'first and foremost a way of thinking about experience' (Connelly and Clandinin 2006: 477). Narrative inquiry suits me best since it is also a form of 'purposive communication' that occurs 
as 'somebody telling somebody else, on some occasion, and for some purposes, that something happened to someone or something' (Phelan and Rabinowitz 2012: 3). As a creative writer, I aim to encapsulate cultural and ethnic alienation as I have experienced it. In this article, I discuss how the Scapegoat and the Tragic Hero archetypes in contemporary short story practice can explore experiences of marginalisation due to race, ethnicity and religious faith, why these archetypes suit my purposes, and how this creative choice shapes my narrative writing.

Archetypes are full of numerous symbolic affiliations (either fictional or metaphorical, such as the affiliation of the white lily with purity, and the red rose with passion) and have certain force and meaning, which are derived from universal human experience and cultural context, dictated by a specific dogma (Friedman 1975: 304; Rowland 1999: 10). The use of archetypes in narrative creation helps to set the cultural characteristics and indicators defining that particular narrative work, making it recognisable (Snowden 2001: 1). According to Evans and Finestone (1971), the Scapegoat-being one of the four primordial archetypal characters in literature and art-is the manifestation of the individual or object that is blamed and sacrificed for whatever is wrong with the society. On the other hand, Frye states that the Tragic Hero archetype-which was once central to tragic drama in fifth century Athens and seventeenth century Europe-has heroic traits but is involved both with a sense of his relation to society and with a sense of the supremacy of natural law, both of which are ironic in reference' (2000: 37). In this article, I focus on the Scapegoat and the Tragic Hero archetypal characters, since they have manifested themselves well in the characters in my short stories as well as my intercultural experience as a double minority.

\section{Writing 'Her Tale on Earth' and 'The Day She Walked Out of the Gates'}

Whenever I have something to write, I have always tried to compose it in the form of a short story, regardless of whether I might intend to develop it into something longer, like a novel. A short story-a brief story between 1,000 and 10,000 words (Frakes 1959: 1)-must have 'the single effect' or 'the effect of totality', making it 'complete', 'self-contained', and 'concise' (Matthews 1961: 36-37). March-Russell also suggests that a short story has, at its base, roots in folktales, fairy tales, and myths (2009: 12). He emphasises that ancient tales have become the bedrock of the society, thus with some adjustment to the realistic world, they have transformed into the forms of short story we are familiar with today (March-Russell 2009). Supporting this statement, Shaw writes that the short story, similar to any kind of narrative, changes through time and has the capacity to encapsulate events and relate these to older tales of origin (2013: 20). In my own creative work, I am drawn to the way the short story concisely conveys these links to myths and archetypes.

My story 'Her Tale on Earth' is narrated from the first person point of view of Dave, an emotionally troubled young man who writes about Scarlet, a deceased orphaned girl who once became his childhood friend. As the story progresses, it later turns out that Scarlet was Dave's half-sister and an illegitimate child. This situation explains her 
status as an outcast, who was later murdered by her bullying peers in that small town. At that moment, Dave finally understood why people disliked Scarlet and tried to make her life miserable, and why they gossiped about his parents. In creating the twist in the form of a rude awakening, I tried to convey this shocking realisation through the following passage:

‘She’s gone now. Are you happy?’ It was my father’s angry voice. He was crying.

A gallant laugh from my mother. 'Why shouldn't I? Now there's nothing that can bother me again when I step out of the house. Those bullying school-girls actually did me a favour. Our neighbours will soon forget it because the little beast is gone. Our life will be the same as the way it was.'

'No, it won't. She's my child, Amber. Scarlet is my own flesh and blood. We should have taken care of her under our protection from the very beginning. We could have saved her from an early grave.'

'Dave is your flesh and blood,' my mother snapped, 'and he will be your only son and heir to the family. It's your own fault that she died. You're the one who started the affair, and now the game is over. You've paid the price at last. She's a disgrace from birth, someone who shouldn't have been born. The quicker you accept it, the better our life will be from now on. It's a shame I couldn't keep Dave more at home because I had to work. Now he's emotionally attached to that girl.'

Scarlet embodies the Scapegoat archetype since she is perceived as Dave's family's 'disease' who eventually has to be sacrificed and permanently discarded in order to improve his family's reputation in the community. Scarlet is representative of ethnic minorities and the underprivileged who constantly face marginalisation and alienation, and at the same time struggle to conform to the ways of the majority. Scarlet, as the abused child, represents what is considered the 'lost soul' here. From the perspective of Dave's family, the family's happiness and peace can only be achieved in exchange for one child's suffering and eventual death. The unfairness that exists in the story-one having to lose so others can win-has been explored time and time again in short stories.

To elucidate my point, similar archetypes can be applied and detected in other short stories, such as Ursula Le Guin's (1975) 'The Ones Who Walk Away from Omelas', one of the best stories that embodies the Scapegoat archetype. The story revolves around the blissful, utopian city of Omelas, of which its goodness depends on the suffering of a child (of unknown gender) who is kept sealed away in a dark, cellar broom closet. Despite the people's awareness and pity for the imbecile child, they are unable to do anything since improving the child's condition would bring destruction upon their beloved city. This kind of story, which Bruce Brandt describes as 'An analogous use of a suffering child to frame a moral challenge' (2003: 53), strongly resonates with any 
society in any given time; however advanced and prosperous one has become, there will always be misfits or outcasts perceived as the Other, upon whom blame is projected, polarising them from the collective unconscious. As Le Guin remarks, the suffering child materialises the timeworn idea of the Scapegoat (1975: 275), or as Brandt puts it, 'an innocent who suffers for the sake of the community as a whole' (2003: 54).

My second story draws on the archetype of the Tragic Hero to portray one's inability to accept the collapse of idealised cultural homogeneity. 'The Day She Walked Out of the Gates' is told from the third person point of view, narrating the tale of a young woman named Eliza, a young Christian, Chinese-Indonesian woman who chooses to marry Darystya, a Javanese Muslim. Her father (Harry) strongly opposes the marriage of his beloved daughter and decides not to give his blessings. Eliza comes from an ethnic minority family, while Darystya comes from an ethnic majority family. The Tragic Hero archetype is embodied in the fate of Eliza's father as he dies of heartbreak over his daughter's choice of marriage. On the other hand, Eliza represents minority people who often face dilemma when they want to be included as members of the society, as they are somehow required to cast aside most of their identity features in order to be able to embrace their new identity as part of the majority:

Eliza turned her face toward him and smiled. 'My sister called.'

'Which one? Elaine or Elinor?'

'Elaine. Father passed away an hour ago from a heart attack. He didn't even make it to the hospital. She was choking and wailing at the end of the line, saying mother fainted and has not recovered. Now they're arranging things for the funeral and informing our relatives and colleagues. She asked if I could come and lend a hand as soon as possible.'

There was a long, haunting silence that followed. 'I'm so sorry, my dear. I'm so sorry you weren't there to bid him farewell and witness his last moments and hold his hand,' Darystya spoke softly, almost guiltily. 'I know how much you love him.' He hated to be reminded over and over that he was the reason for pushing the father-daughter relationship to the brink of an abyss.

Eliza's father, with hardness of his heart and drawing from the collective unconscious around him, insists that the root of his daughter's marriage lies in Eliza's foolishness and insensibility to choose a member from another cultural group as her husband. Ironically, through his resolute disapproval, he unconsciously sets himself up to become the Tragic Hero. Clutching his beliefs, he thinks that by not giving his blessing he is 'saving' the face of his own cultural group, yet he finally succumbs to a lonely death because he could not see his own flaws and reconcile with his daughter. If seen from the perspective of Eliza's father, it is evident that he thinks that Eliza is a lost 
cause, a daughter with a troubled mind who chooses all the wrong options in her life by committing apostasy. He has failed to see that the unwritten code within the society dictating that members of the two groups should never mingle intimately, is the actual problem, and this failure has made him into a pitiful and ironic chivalrous figure.

The Tragic Hero has roots in ancient Greek tales. For example, Prometheus the Titan is shunned by the gods for befriending and helping men (Frye 2000). His act in rebelling against the gods by stealing fire and giving it to civilised men is deemed heroic but tragic as instead of gaining praise, he receives punishment. Prometheus has to suffer for sympathising with the mortal mankind, and this kind of suffering is also seen as having a tragic effect (Frye 2000). Another ironic archetypal hero is the biblical figure of Jesus Christ, who is described as 'the perfectly innocent victim excluded from human society' (Frye 2000: 42). Despite his attempts to atone for the sins of men, he still had to suffer society's persecution and die on the cross.

In terms of addressing the collective issue that serves as the backdrop of my second story, Jung argues that:

A collective problem, if not recognized as such, always appears as a personal problem, and in individual cases may give the impression that something is out of order in the realm of the personal psyche. The personal psyche is indeed disturbed, but such disturbances need not be primary; they may well be secondary, the consequence of an insupportable change in the social atmosphere. The cause of disturbance is, therefore, not to be sought in the personal surroundings, but rather in the collective situation (1989: 233-234).

The collective situation in 'The Day She Walked Out of the Gates' is indeed problematic, as it represents a society's strong rejection of interreligious and interethnic union in marriage, despite its otherwise contemporary advancement and cosmopolitan orientation. Since the root of the issues in both of my short stories derives from community involvement and family affairs, the activated archetypes-the Scapegoat and the Tragic Hero-are naturally connected to the representations of family dynamics and cultural interference. Activated archetype is a the term I use to describe character types that emanate from the writing process and lead the story while also embodying the essence of the narrative. David Lindenfeld argues that if the family was the decisive locus for socialization in childhood, then the broader sociocultural trends of a person's environment played a decisive role in the later stages' (2009: 220). In 'Her Tale on Earth', this is hinted in Dave's angsty teenage environment-his way of communicating his anger at Scarlet's treatment by his mother and the wider community. His anger leads him to the wrong crowd and he is involved in a motorbike accident, impeding his schooling. Dave's familiar voice in narrating Scarlet's tale has somehow grown into something that speaks beyond my own voice, thoughts and acts of disobedience-the evidence that when one is truly engrossed in an association with the activated archetype, it 'summons up a voice stronger than our own' (Jung 1966: 82). The same can also be said with 'The Day She Walked Out of the Gates', with my voice and thoughts embedded in the various characters that emerge within the flow of the narrative. An activated archetypal image is immensely powerful, as Jung contemplated, and Hillman elaborates: 
One thing is absolutely essential to the notion of archetypes: their emotional possessive effect, their bedazzlement of consciousness so that it becomes blind to its own stance. By setting up a universe which tends to hold everything we do, see, and say in the sway of its cosmos, an archetype is best comparable with a God (Hillman 1975: xix).

Archetypes, in the case of my short stories, have fulfilled their godlike heroism and mixed it with tragedy as both a social and moral fact. As the Scapegoat and the Tragic Hero become the centre of the stories, they embark on journeys that address questions of morality, life's meaning, and the ways of God in the way they portray judgement and contemplation towards incidents happening to them along the way. The inevitability of the consequences of their actions form a paradox that does not merely depend on their moral status. Instead, this inevitability is just something that Frye has identified as 'Aristotle's hamartia or "flaw", which 'is not necessarily wrongdoing, much less moral weakness', but might be simply 'a matter of being a strong character in an exposed position' where having a godlike position or being in a place of leadership, 'a character is exceptional and isolated at the same time' (2000: 38). Thus, both archetypes used in my creative work have shown how their personal choices and external circumstances can overlap one another, be entangled and eventually shape their tragic fate.

\section{Conclusion}

Reflecting on using the Scapegoat and the Tragic Hero archetypes in both of my stories, 'Her Tale on Earth' and 'The Day She Walked Out of the Gates', the process of development and experimentation with the archetype has enabled me to crystalize the experience of undergoing alienation which is an integral aspect of the narrating process. Using the two archetypes has enabled me to follow a certain narrative pattern which set the stories on their paths, since they can serve as the tools that carry 'ambiguities, complexities and ironic relationships' (Bolton 2010: 217), and that each character created 'is an aspect of the author' (Bolton 2010: 217). Boynton insists that the reason why we keep telling specific stories over and over is that 'they carry for us truths about ourselves and especially about how we look at the world' (Boynton 1992: 32). Corresponding to this statement, Jung argues that creative work "consists in the unconscious activation of an archetypal image and in elaborating and shaping the image into the finished work' (1966: 82). The finished works, my two short stories, are the culmination of what Elizabeth Nelson calls 'a collaboration of psyche and scholar that molds the text in deep and sometimes unnamable ways' (2013: 333). These two last arguments coincide with my choice of producing these two short stories, particularly since the formulation of fiction through narrative inquiry facilitates writers to 'head straight for the heart of the matter' (Rowland et al. 1990: 291). 
cind e r

\section{Acknowledgements}

I am grateful for the reviewers' constructive comments on this paper. I especially appreciate being advised to insert another archetype, the Tragic Hero, which better embodies my second story. I would also like to acknowledge that this paper was written with the support of a Higher Degree by Research Scholarship. 
cind e r

Works Cited List

Bolton, Gillie 2010 Reflective Practice: Writing \& Professional Development London and California: Sage

Boynton, Robert W and Mack, Maynard 1992 Introduction to the Short Story Portsmouth: Boynton/Cook Publishers

Brandt, Bruce E 2003 'Two Additional Antecedents for Ursula Le Guin's "The Ones Who Walk Away from Omelas"' ANQ: A Quarterly Journal of Short Articles, Notes and Reviews 16 (3), 51-56

Connelly, F Michael and Clandinin, D Jean 2006 'Narrative Inquiry' in L L Green, G Camilli, \& P Elmore (eds) Handbook of Contemplary Methods in Education Research New Jersey: Lawrence Erlbaum, 477-487

Evans, Oliver, and Finestone, Harry 1971 The World of the Short Story: Archetypes in Action (Edited with Introductions by Oliver Evans and Harry Finestone) New York: Alfred A Knopf

Frakes, James R, \& Traschen, Isadore 1959 'Reading the Short Stories' in James R Frakes \& Traschen, Isadore (ed) Short Fiction: A Critical Collection New Jersey: Prentice-Hall

Friedman, Norman 1975 Form and Meaning in Fiction Athens: The University of Georgia Press

Frye, Northop 2000 Anatomy of Criticism: Four Essays Princeton and Oxford: Princeton University Press

Hillman, James 1975 Revisioning Psychology New York: Harper Colophon

Jung, Carl 1966 [1931] 'On the relation of analytical psychology to poetry' in C G Jung (ed), The spirit in man, art and literature (The collected works, R F C Hull, (trans $2^{\text {nd }}$ ed) Princeton: Princeton University Press, 15, 65-83

Jung, Carl 1989 [1961] Memories, Dreams, Reflections revised edition New York: Vintage

Jung, Carl, and Chodorow, J 1997 Jung on Active Imagination (Key readings selected and introduced by Joan Chodorow) London: Routledge

Le Guin, Ursula 1975 'The Ones Who Walk Away from Omelas' The Wind's Twelve Quarters New York: Harper, 275-284

Lindenfeld, David 2009 'Jungian Archetypes and the Discourse of History' Rethinking History 13 (2), 217-234

March-Russell, Paul 2009 The Short Story: An Introduction Edinburgh: Edinburgh University Press

Matthews, Brander 1961 'The Philosophy of the Short Story' in Eugene Current-Garcia \& Patrick, Walton R (ed) What is the Short Story? Chicago and Atlanta: Scott, Foresman and Company

Nelson, Elizabeth 2013 'Writing as method: Depth psychological research and archetypal voice' International Journal of Multiple Research Approaches 7 (3), 330-342 
Phelan, James, and Rabinowitz, Peter J 2012 'Narrative as Rhetoric' in Herman, David et al (eds) Narrative Theory: Core Concepts and Critical Debates Columbus: The Ohio State University Press, 3-8

Rowland, G, Rowland, S, and Winter, R 1990 'Writing Fiction as Inquiry into Professional Practice' Journal of Curriculum Studies 22, 291-293

Rowland, Susan 1999 C G Jung and Literary Theory: The Challenge from Fiction New York: Palgrave Macmillan

Shaw, Valerie 2013 The Short Story: A Critical Introduction New York: Routledge

Snowden, David J 2001 'From storytelling to narrative: Archetypes as an instrument of narrative patterning' Knowledge Management 5, 1-6

Stevens, Anthony 1994 Jung: A Very Short Introduction Oxford: Oxford University Press 